\title{
Review of transactions in taste: the collaborative lives of everyday Bengali foods, by Manpreet K. Janeja
}

\author{
David Sutton
}

\section{Book details}

Manpreet K. Janeja: Transactions in Taste: The Collaborative Lives of Everyday Bengali Foods. London: Routledge, 2010. 185 pages, ISBN 978-0-415553742.

\section{Book review}

As suggested in the title, Transactions in Taste is about how food 'collaborates' with humans in the creation of a sense of the everyday or normal. The book is ethnographically based in Bengal; that is, in both West Bengal (India) and East Bengal (Bangladesh), in the cities of Calcutta and Dhaka. Like much recent work in the anthropology of food, the concern is over questions of identity, and how it is parsed out among competing, contrasting and overlapping categories, such as Hindu and Muslim, India and Bangladesh, and middle class and poor. The book's primary influence is the theory of art and agency developed by anthropologist Alfred Gell, which posits objects as 'actants' (p. 19) that can translate, transform, betray or in other ways shape human intentionalities. Janeja ties this approach to the notion of a 'foodscape', or the ways that food and food practices create a sense of place, or desh, such that 'what is revealed is not only people's affection for desh but also that desh has affection for its people, that is, desh as place is emotionally involved with people' (p. 51). This leads to some interesting phrasings on the part of the author, who describes a preparation of mashed chilies that 'attaches itself to the mistress ... touches her, wraps her in its embrace, dissolves her bodily boundaries, and enters her. It makes: her eyes water, her face turn red, her cough, and her lose her temper' (p. 91; original emphasis). By making explicit the agency ascribed to food, Janeja is making an important point about how we experience food as not simply responsive to our desires but shaping our environments and our very sense of normality and identity.

Correspondence: dsutton@siu.edu

3538 Faner Hall, Southern Illinois University, Carbondale, IL 62901-4502, USA
While Janeja considers a number of topics under this rubric, including notions of purity and pollution, hospitality, and the 'idle talk' (p. 103) about food that occurs in tea shops, I want to highlight two issues in particular. Over the course of several chapters she describes the tense interactions between a middle-class East Bengali mistress and her hired cooks/servants. What is brought out here is their failure to reproduce normality by cooking the flavors of their own rather than their mistress's desh. This is because they cook hot chilies when they think their mistress will be gone for the afternoon only to have her return home early (indeed, the sensory description above is taken from this incident). Thus a failure to reproduce normality leads to the firing of one of the two cooks. This is not only because of the way the chilies pervade the household with the smells of the cooks' desh, but because of fears of the mistress that hot chilies also can lead poor servants to acts of violence and sexual immorality. This incident is interesting both because of the agency ascribed to normal and not-normal foods, but because it shows the competing 'normalities' that make up everyday life in East and West Bengal - it is the servants' desire for a 'normal' meal that reminds them of their desh and leads them to take the risk of preparing these chilies.

A later chapter considers the way taste is commodified in restaurants in Calcutta and Dhaka. Janeja shows the processes by which female home-cooking is transformed to make it acceptable in the public sphere. While this chapter contains rich materials that will interest other scholars working on restaurants, it was particularly interesting to see her description of the process by which restaurateurs set themselves up as preservers of a tradition (as always on the verge of being otherwise lost), while at the same time balancing and modifying the dishes to make them acceptable to their customers: 'Normality then is defined here as the capacity of the cooks to exclude their respective desh as an actant in their continuous performance of the strategic 
replication of 'standard' or 'medium' Bengali food that is normal in Calcutta in the perceptions of the restaurant staff' (p. 131). While this process may be occurring in many different sorts of restaurants around the world, it comes into focus in Janeja's careful description of the treatment of ingredients, spices, and the temporal aspects of creating marketable flavors. Janeja also discusses this in relation to notions of ownership of cultural and intellectual property. She suggestively concludes that ethnic conflicts may arise not over differences as much as over irreconcilable claims or aspirations to the same identities. In these situations, it is the perceived similarities of the ethnic Other that are experienced as threatening, rather than the differences' (p. 163; original emphasis).

This is a rich ethnography, with many sensory descriptions (for example, making mashed rice balls is described as 'chewing with the fingers' (p. 59)). It is enlivened by the inclusion of 23 color plates; I wish more publishers were willing to include such plates in scholarly works on food. However, the writing is often quite dense, and in many parts the text is swamped by footnotes, making it more appropriate for scholars than the casual reader or student. It is not the first ethnography to be inspired by Gell's approach, and the interested reader should be aware of Joy Adapon's Mexican-based ethnography Culinary Art and Anthropology [1]. The importance of continued work that explores the agency of food and of the kitchen environment in creating the strong sensory and emotive qualities of normality, social identities and divisions, and the qualities of flavor is testified to in both these works that take inspiration from Alfred Gell's theories of art and the agency of objects.

\section{Competing interests}

The author declares that he has no competing interests.

Received: 1 July 2013 Accepted: 5 July 2013

Published: 18 July 2013

\section{References}

1. Adapon J: Culinary Art and Anthropology. Oxford: Berg; 2007

\section{doi:10.1186/2044-7248-2-22}

Cite this article as: Sutton: Review of transactions in taste: the collaborative lives of everyday Bengali foods, by Manpreet K. Janeja. Flavour 2013 2:22.

\section{Submit your next manuscript to BioMed Central and take full advantage of:}

- Convenient online submission

- Thorough peer review

- No space constraints or color figure charges

- Immediate publication on acceptance

- Inclusion in PubMed, CAS, Scopus and Google Scholar

- Research which is freely available for redistribution 